\title{
Long-term effects of land use on perinatal mortality in the Endangered Saimaa ringed seal population
}

\author{
Lauri Liukkonen ${ }^{1, *}$, Anni Rautio ${ }^{1}$, Tero Sipilä ${ }^{2}$, Marja Niemi $^{1}$, Miina Auttila ${ }^{2}$, \\ Jouni Koskela ${ }^{2}$, Mervi Kunnasranta ${ }^{1,3}$ \\ ${ }^{1}$ University of Eastern Finland, Department of Environmental and Biological Sciences, 80101 Joensuu, Finland \\ ${ }^{2}$ Metsähallitus, Parks \& Wildlife Finland, 57130 Savonlinna, Finland \\ ${ }^{3}$ Natural Resources Institute Finland, 80100 Joensuu, Finland
}

\begin{abstract}
Human disturbance can affect the viability of wildlife populations partly through its effects on breeding success. Land use as a form of disturbance may do so by fragmenting the key environments of certain species. We used statistical pattern recognition methods to estimate the long-term effects of human disturbance on the Endangered, landlocked population of the Saimaa ringed seal Pusa hispida saimensis by examining how various densities of buildings on lake shores have altered the survival of juveniles and the persistence of the population. In addition, we examined whether disturbance caused by different intensities of land use would further reduce the long-term persistence of the population. We also provide estimates of the quality of Lake Saimaa shorelines as breeding habitat in relation to building density. Our results show that at present, the lairs of Saimaa ringed seals are located closer to potential sources of human disturbance than they were in the past and that land use intensity has an effect on juvenile mortality. Perinatal mortality increases significantly in more densely developed areas, where the nearest building is within $800 \mathrm{~m}$ of a birth lair. In addition, $29 \%$ of the shoreline of Lake Saimaa is no longer suitable for ringed seals due to intensive land use. Our results illustrate how human disturbances can significantly compromise juvenile survival and therefore the long-term existence of this Endangered population.
\end{abstract}

KEY WORDS: Pusa hispida saimensis - Juvenile mortality $\cdot$ Population change $\cdot$ Anthropogenic disturbance $\cdot$ Land use

\section{INTRODUCTION}

Humans and wildlife are living in closer mutual interaction than ever before, and increasing numbers of species and taxa are suffering from the direct or indirect effects of human disturbance. Many bird and mammal species avoid areas that are being disturbed by human activity (Stevens \& Boness 2003, MoránLópez et al. 2006, Leblond et al. 2013), whereas other species exhibit behavioural plasticity that allows them to adapt to a human presence (Díaz-Ruiz et al. 2016, Wheat \& Wilmers 2016). It may not always be possible for a species to avoid human interference or

*Corresponding author: lauri.liukkonen@uef.fi to become accustomed to it, due to limited behavioural flexibility, limited mobility or the scarcity of suitable habitats. In such cases, a disturbance may have severe immediate effects at the individual level (such as increases in heart rate or stress hormone levels), which may ultimately affect the viability of the population (e.g. Regel \& Pütz 1997, Weimerskirch et al. 2002, Ellenberg et al. 2006, 2007, Selman et al. 2013). Also, these immediate responses may be transformed into long-term changes and hence adversely influence demographic parameters such as survival and reproductive success (Fowler 1999, Frid \& Dill 2002, Weimerskirch et al. 2002, Müllner et al. 2004, 
Ellenberg et al. 2006, 2007). Thus, understanding the long-term effects of human disturbance on wildlife is one of the key elements in population management, especially for endangered species.

The Saimaa ringed seal Pusa hispida saimensis is an Endangered subspecies of the ringed seal (Kovacs et al. 2012, Liukko et al. 2016) that lives in Lake Saimaa, a freshwater lake that was isolated from the Baltic basin after the last Ice Age, about 9500 yr ago (Nyman et al. 2014). The decline in this landlocked population was most acute during the 20th century, on account of various factors such as hunting, environmental toxins, habitat fragmentation and incidental by-catch mortality (Sipilä \& Hyvärinen 1998, Kokko et al. 1999, Sipilä 2003). As a result of active conservation efforts, the population has now increased to over 350 individuals (Metsähallitus Parks \& Wildlife Finland 2016), but there are still several factors affecting its viability. The low genetic variation within the population has reduced its ability to adapt to environmental changes, and therefore an increase in population size would be essential (Valtonen et al. 2012). One of the major factors slowing down population growth is still the by-catch mortality among juveniles, particularly in connection with gillnet fishing (Niemi et al. 2012, 2013a). Regional and temporal fishing restrictions and prohibitions have therefore been introduced in the most important breeding areas. In addition to this by-catch mortality, an average of $13 \%$ of the total of around 60 pups born annually are either stillborn or die during the nursing period (Auttila et al. 2014, Auttila 2015), the reason for which has remained unclear. Furthermore, the effects of disturbances are being intensified as the climate changes and breeding conditions deteriorate, due to the inadequate snow and ice cover (Auttila 2015).

The ringed seals of Lake Saimaa give birth to a single pup in a subnivean lair during a period from mid-February to mid-March (Helle et al. 1984, Sipilä 1990), and weaning takes place in mid-May (Niemi et al. 2013a). In general, the lairs are used for resting, breeding and nursing as they provide protection against the harsh thermal conditions and against predators. Saimaa ringed seals exhibit high site fidelity (e.g. Kunnasranta 2001, Koskela et al. 2002, Valtonen et al. 2015), and areas with low human activity are preferred as breeding sites (Sipilä 1990). The subnivean lairs are typically located in snowdrifts on the shores of small islands or islets, where deep snowdrifts tend to form in approximately the same spot every year (Helle et al. 1984, Sipilä 1990). The mother and her pup stay close to the lair during the nursing period (Rautio et al. 2009, Niemi et al. 2013a), which emphasizes the importance of the surroundings of the lair site. Lake Saimaa is also a popular place for leisure-time pursuits, and human activity on the lake during the seals' breeding season is continuously increasing. There are now around 60000 buildings close to the shoreline, and many outdoor activities take place on the lake. Furthermore, 300 to 400 new buildings are built on the shores of the lake each year, and an increasing proportion of the cottages are being used all year round (Ministry of the Environment 2011).

Some evidence indicates that human disturbance affects the moulting of Saimaa ringed seals in spring, when they are forced to enter the water from their haul-out sites as they are either intentionally or unintentionally approached by boats (Niemi et al. 2013b). Harbour seals Phoca vitulina have also been observed to avoid contact with humans (Henry \& Hammill 2001, London et al. 2012, Blundell \& Pendleton 2015), and the most critical time for this is thought to be the breeding period. Several studies of pinniped species have indicated that the presence of humans increases pup mortality (Kenyon 1972, Mattlin 1978, Kovacs \& Innes 1990, Stevens \& Boness 2003), and there have been suggestions that such disturbance can also affect the breeding success of Saimaa ringed seals (Sipilä 2003, Ministry of the Environment 2011), although the long-term effects on the population are difficult to quantify. In particular, the direct observation of human-induced disturbances in the case of an endangered species is challenging, if not impossible, and thus statistical pattern recognition tools are needed in order to estimate the risks attached to such disturbances.

Here we examined to what extent land use may be a factor in breeding success and juvenile mortality observed in the Endangered Saimaa ringed seal. We addressed 2 issues related to the effects of human disturbance: the probability of perinatal pup death in relation to land use intensity, and the quality of the shores of Lake Saimaa as breeding habitats for ringed seals. Our results should prove useful in connection with shoreline land use planning, e.g. for updating master plans in the distribution area of the ringed seal or for deciding whether to issue a building permit for a site on the shore of Lake Saimaa.

\section{MATERIALS AND METHODS}

This study covered the whole current and potential distribution area of the ringed seal Pusa hispida 
saimensis (see Niemi et al. 2012) in Lake Saimaa $\left(61^{\circ} 05^{\prime}\right.$ to $62^{\circ} 36^{\prime} \mathrm{N}, 27^{\circ} 15^{\prime}$ to $30^{\circ} 00^{\prime} \mathrm{E}$, Fig. 1). The lake (surface area $4400 \mathrm{~km}^{2}$ ) is fragmented, with numerous interconnected water basins and $>14000 \mathrm{~km}$ of shoreline and $>13000$ islands. It is about $180 \mathrm{~km}$ long and $140 \mathrm{~km}$ wide, and has a mean depth of $12 \mathrm{~m}$ (Kuusisto 1999). It is normally covered by ice approximately from mid-December to the end of April (Oiva 2015).

Saimaa ringed seal lair site data for 1995-2013 (Metsähallitus Parks \& Wildlife Finland database 2013) and shoreline building location data (Population Register Centre, Population Information System, Building and Dwelling Register database 2013) were used to estimate the effects of human disturbance in the form of land use on perinatal mortality (i.e. stillborn pups and pups that lived for less than $2 \mathrm{mo}$ ). The lair site location data had been acquired during the annual censuses (Sipilä 2003), and the shoreline buildings ( $n=68620$ ) used in the analyses were identified from the spatial database by employing a $200 \mathrm{~m}$ buffer with respect to the shoreline. The input data consisted of the locations (latitude and longitude) of

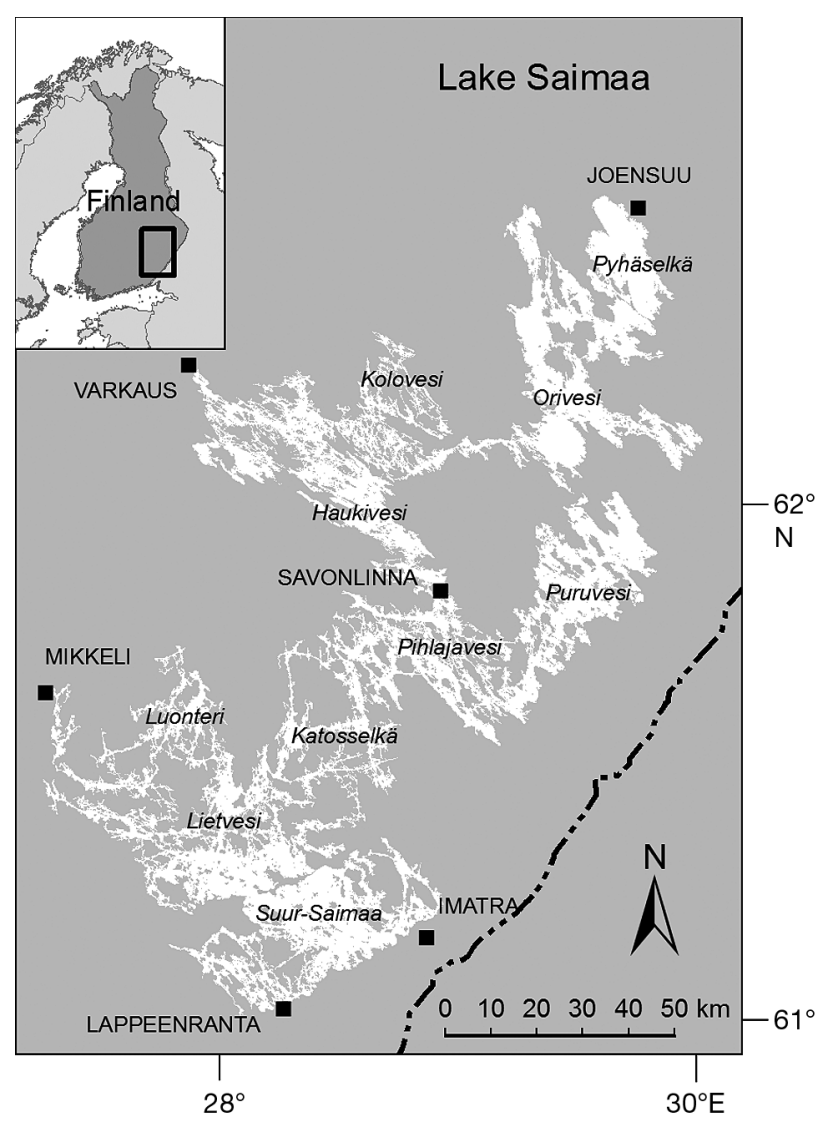

Fig. 1. Water basins of Lake Saimaa, Finland. Towns (>20000 inhabitants) are marked with birth lairs ( $\mathrm{n}=1113$, used by females and their pups), haul-out lairs ( $\mathrm{n}=6582$, used by males or by females without pups) and deaths $(\mathrm{n}=175)$ of nursed (age $0-$ $2 \mathrm{mo}$ ) and stillborn pups (foetal deaths) and their distances from the 1st, 2nd, ..., 100th nearest building. The procedure for estimating perinatal mortality included the distances of dead (including stillborn and nursed pups) and live nursed pups found in the birth lairs in year $y$ from the 1 st, 2 nd, ..., 100th nearest buildings that had been constructed by the end of year $y-1$ (i.e. 2-4 mo before observing a dead or alive pup in year $y$ ). Breeding success was estimated on the basis of the distance of each haul-out lair from the $1 \mathrm{st}, 2 \mathrm{nd}, \ldots, 100$ th nearest buildings in year $y-1$, the distributions of which were compared with the distances of the birth lairs from the $1 \mathrm{st}, 2 \mathrm{nd}, \ldots, 100 \mathrm{th}$ nearest buildings in year y (11 mo gestation; Atkinson 1997).

The probability of perinatal mortality with respect to the distance of each birth lair from the 1st, 2nd, ..., 100th nearest buildings was estimated using the random forest (RF) classifier (Breiman 2001), an ensemble learning method that constructs a collection of decision trees and uses the idea of bagging (bootstrap aggregation; Breiman 1996) to control for variance. The RF model is able to handle many possibly correlated variables, and hence the perinatal mortality probabilities were modelled using distances from the 100 nearest buildings. The parameters of the RF model (number of trees, confidence, minimum gain) were estimated using 10fold cross-validation (Kohavi 1995). After estimating the parameters, the optimized RF model was applied in relation to the distances from the 100 nearest buildings at $1 \mathrm{~km}$ intervals along the shoreline of the lake.

The distances of the birth lairs from the $1 \mathrm{st}, 2 \mathrm{nd}, \ldots$, 100th nearest buildings were compared with those of the haul-out lairs, in order to recognize breeding success patterns with respect to distance from the $1 \mathrm{st}$, 2nd, ..., 100th nearest buildings. This was done using a semi-supervised one-class support vector machine (OCSVM) (Cortes \& Vapnik 1995, Schölkopf et al. 2001, Chang \& Lin 2011). (OC)SVMs have usually been used for ecological niche modelling, geographical GIS modelling, species distribution modelling and various remote sensing modelling applications, for example (Drake et al. 2006, Foody et al. 2006, Muñoz-Marí et al. 2007, Guo et al. 2011). The semisupervised OCSVM differs from the conventional supervised classification model in that it is trained using only 1 class (here the distances of the birth lair from the 100 nearest buildings), after which samples 
from the second class (here the distances of the haulout lair from the 100 nearest buildings) are compared with the above (birth lair distances) in the testing (10-fold cross-validation) phase. The OCSVM estimates the overlap between the distributions of the 2 classes using confidence values given for each sample, where a confidence $>0$ means a regular (usual, common) breeding distance from the $1 \mathrm{st}, 2 \mathrm{nd}, \ldots$, 100th nearest buildings and $<0$ means an exceptional (outlier) breeding distance. The confidences were used to map high-low areas of overlap between the 2 groups (breeding success). The OCSVM further distributes each exceptional lair as (1) exceptionally close to or (2) exceptionally distant from the 1st, 2nd, ..., 100th nearest building (Fig. 2). The OCSVM tolerates possibly correlated variables (predictors), and hence the distances of the lairs from the 100 nearest buildings are used here as predictors.

In the preprocessing phase, the distances between the lairs and the $1 \mathrm{st}, 2 \mathrm{nd}, \ldots, 100$ th nearest buildings were rescaled between 0 and 1 , while in the estimation phase, the parameters of the radial basis function (gamma, nu) of the OCSVM model were optimized using 10-fold cross-validation. After estimating the parameters, the optimized OCSVM model was applied with respect to the distances from the 100 nearest buildings at $1 \mathrm{~km}$ intervals along the shoreline of the lake. All statistical analyses were performed using RapidMiner 5.3.015 software (Mierswa et al. 2006).

\section{RESULTS}

The average distance of both types of Saimaa ringed seal lair from the nearest buildings gradually shortened over the period 1995-2013, by an average of $167 \mathrm{~m}$ in the case of the nearest building, and 1031 $\mathrm{m}$ for the 100th nearest building (Fig. 3). The average distance of the birth lair from the nearest building in 2013 was 668 m (median $533 \mathrm{~m}$ ) and that of the haulout lair was $600 \mathrm{~m}$ (median $482 \mathrm{~m}$ ).

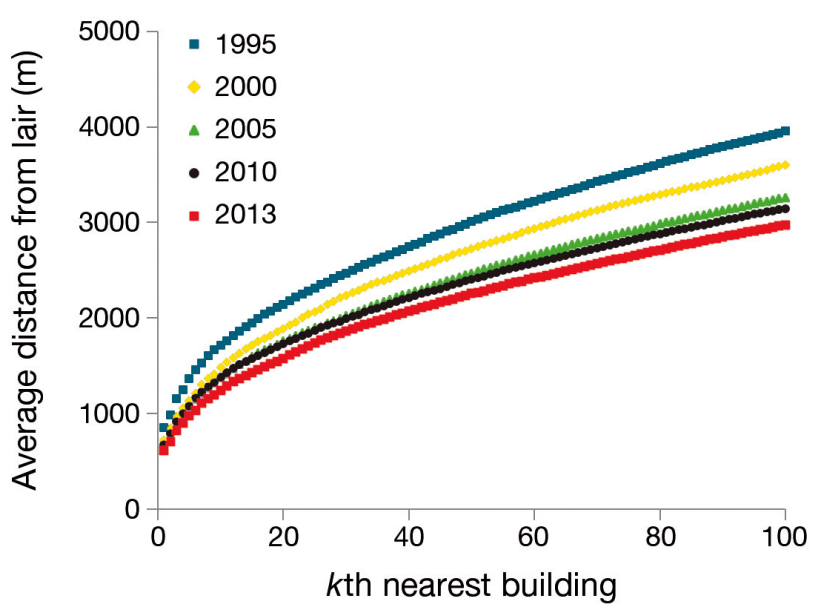

Fig. 3. Average distances between lairs of the Saimaa ringed seal Pusa hispida saimensis and the 1st, 2nd, ..., 100th (i.e. $k$ th) nearest buildings decreased between 1995 and 2013, by an average of $167 \mathrm{~m}$ in the case of the nearest building, and $1031 \mathrm{~m}$ for the 100th nearest building

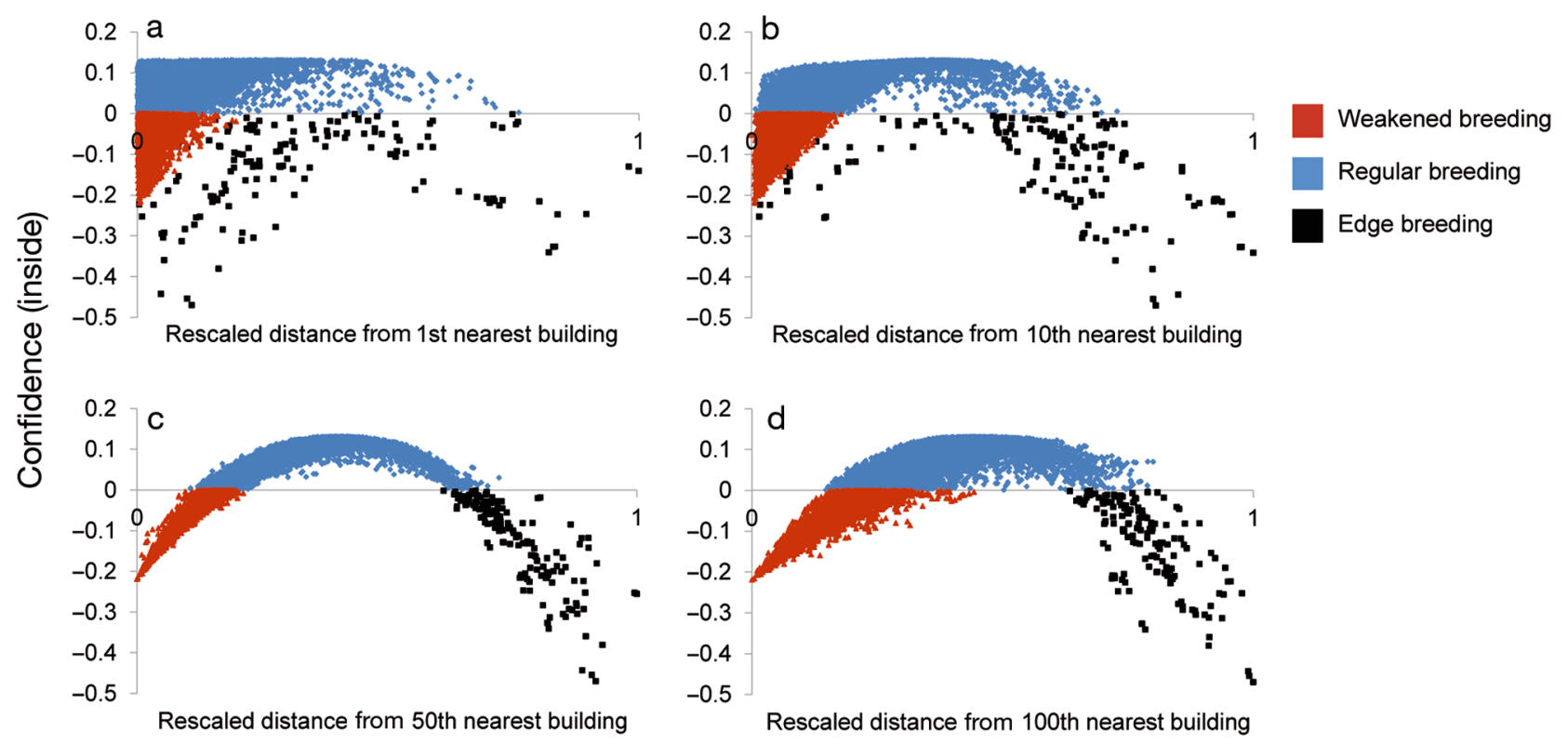

Fig. 2. One-class support vector machine model distribution of Saimaa ringed seal Pusa hispida saimensis lairs on Lake Saimaa as regular (positive confidences, blue dots), exceptionally near (negative confidences, red dots) and exceptionally distant (negative confidences, black dots) from the (a) 1st, (b) 10th, (c) 50th and (d) 100th nearest building 
Close proximity and high density of buildings increased the estimated risk of perinatal mortality (Fig. 4), which increased markedly when the nearest building was less than $800 \mathrm{~m}$ from the birth lair (Fig. 4a) and also increased when the 100th nearest building was less than $3000 \mathrm{~m}$ away from the birth lair (Fig. 4d), indicating that high building density had a negative effect on pup survival. Furthermore, the variation in perinatal mortality probabilities was high $(0-0.72)$ when the nearest building was very close to the birth lair (Fig. 4a), due to the effect of building density on mortality. The average probability of perinatal death over all locations (Fig. 4; dots) was 0.15 (i.e. an observed perinatal mortality of $15 \%)$.

Our OCSVM modelling suggested that the appearance of 1 birth lair required on average 6.6 previous year's haul-out lairs in the regular breeding area. These birth lairs were an average of $673 \mathrm{~m}$ (range 24-2968 m) from the nearest building. The number of
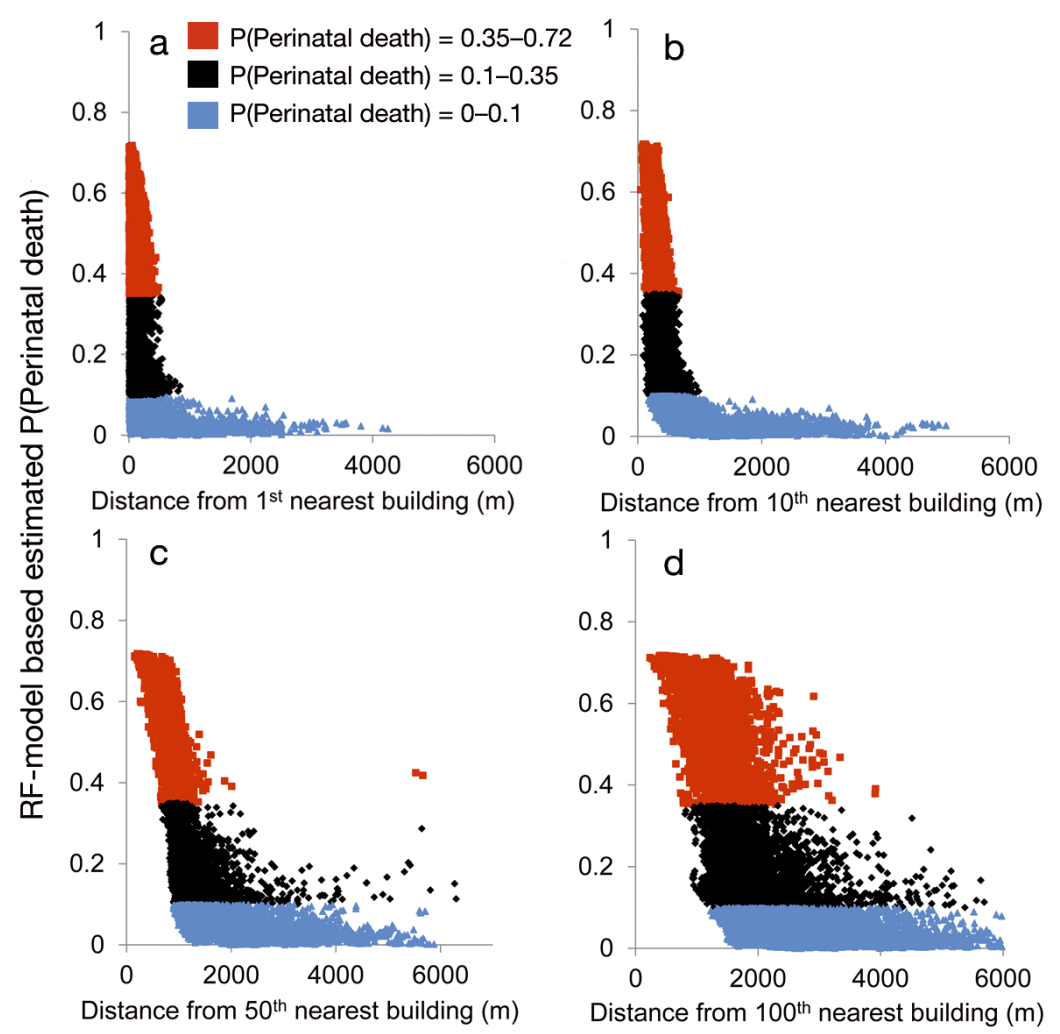

Fig. 4. Random forest (RF) model-based estimates of the probabilities of perinatal Saimaa ringed seal Pusa hispida saimensis pup death. Probabilities were computed for each $1 \mathrm{~km}$ interval of lake shoreline in relation to distances of the birth lair from the (a) 1st, (b) 10th, (c) 50th and (d) 100th nearest buildings. The highest, intermediate and lowest estimated probabilities of perinatal mortality are indicated by red, black and blue dots, respectively (colours correspond to those in Fig. 6a) birth lairs relative to haul-out lairs was exceptionally small at $11 \%$ of the lair sites, namely those located in a densely developed area (with weakened breeding) where the nearest building was an average of $189 \mathrm{~m}$ (range 8-701 m) from the lair site. At these sites, 1 birth lair required 10.4 haul-out lairs in the previous year, but it was also the case that 1 birth lair required a higher than average number of haul-out lairs in sparsely populated areas (with edge breeding) where the nearest building was an average of $1302 \mathrm{~m}$ from the lair (range 390-3237 m). In edge areas, the small number of haul-out lairs was not high enough for regular breeding, and 1 birth lair required an average of 8.4 haul-out lairs from the previous year. The average distances between lairs of Saimaa ringed seals were different in these three predicted OCSVM model-based areas (Fig. 5).

The results based on the RF model suggest that the proximity of buildings increased the probability of perinatal mortality, and that this probability varied between different areas of Lake Saimaa (Fig. 6a), being highest in those close to human population centres.

The shorelines of Lake Saimaa were mostly $(71 \%)$ suitable areas for ringed seal breeding in 2013, or to be more precise, $70 \%$ of the shoreline was classified as belonging to the regular breeding area (the distances between the lairs and buildings were shown by the OCSVM model to be regular), 1\% belonged to the edge breeding area (and was sparsely populated), and $29 \%$ belonged to the weakened breeding area (and were densely built up). In other words, regular breeding is no longer possible on $29 \%$ of the shores of Lake Saimaa (Fig. 6b).

The statistical performance of both models (their 10-fold cross-validation accuracy) was good (RF: $84 \%$ and OCSVM: $92 / 89 \%$, for birth/haul-out lairs, respectively).

\section{DISCUSSION}

Saimaa ringed seals are currently breeding closer to potential sources of human disturbance than previously. Our study has shown that in 2013, the average distance between a seal lair 


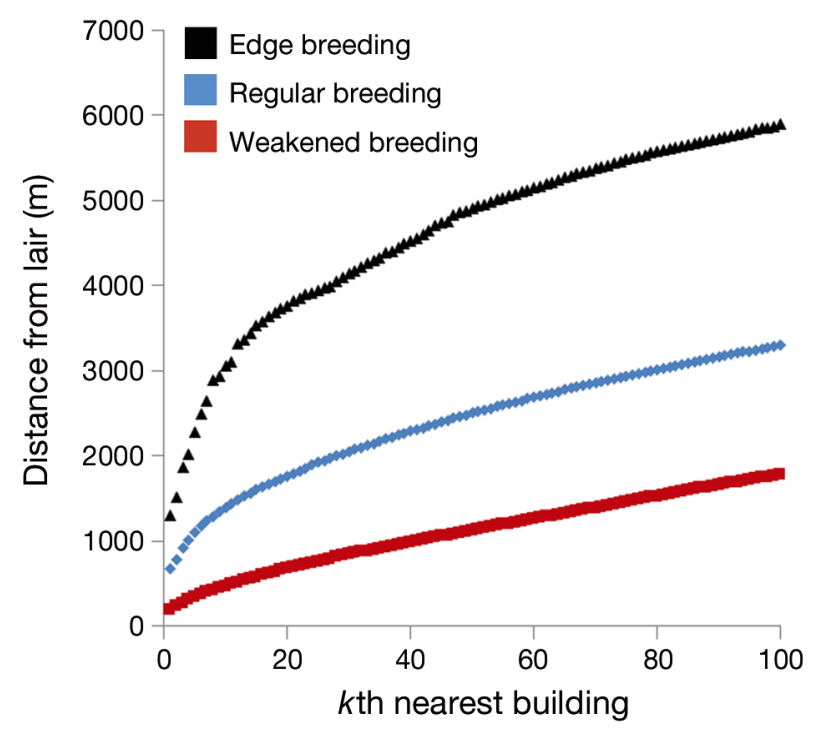

Fig. 5. Average distances between lairs of Saimaa ringed seals Pusa hispida saimensis and the $k$ th $(1 \mathrm{st}, 2 \mathrm{nd}, \ldots, 100 \mathrm{th})$ nearest buildings in cases of edge breeding, regular breeding and weakened breeding areas based on the one-class support vector machine model. The colours shown here correspond to those in Fig. $6 \mathrm{~b}$

and the nearest building was $167 \mathrm{~m}$ closer than in 1995. During that time, the seal population has grown from less than 200 to over 350 individuals (Kunnasranta et al. 2016, Metsähallitus Parks \& Wildlife Finland 2016), and the number of shoreline buildings has also increased. At the same time, the number of leisure-time cottages in Finland has increased by over $20 \%$ (Official Statistics of Finland 2015). It is notable that, being a landlocked subspecies and having a limited freshwater habitat, Saimaa ringed seals live in closer proximity to humans than any other seal population in the world, and given this exceptionally close interaction with humans, some degree of habituation to human presence is likely at the individual level. Other seal species, such as harbour seals Phoca vitulina and harp seals $P$. groenlandica, exhibit a high degree of tolerance to human disturbance, especially during the breeding season (Kovacs \& Innes 1990, Henry \& Hammill 2001, Andersen et al. 2012). It has also been suggested that high tolerance may be linked to a trade-off between escaping and nursing, and hence it may not necessarily be an indication of habituation (Andersen et al. 2012).

Our results strongly indicate that land use as a form of human disturbance has a negative effect on population fitness, in that the probability of perinatal mortality is higher in areas with a high density of buildings. This was shown by the fact that mortality increased significantly when the 100th nearest shoreline building was less than $3000 \mathrm{~m}$ from the location of the birth lair. In addition to building density, the proximity of buildings to the lair site increases the probability of mortality, i.e. perinatal pup mortality increased significantly when the nearest building was located less than $800 \mathrm{~m}$ from the birth lair. This distance is consistent with the results of an earlier telemetry study of Saimaa ringed seal pup home range before weaning (Niemi et al. 2012). Furthermore, similar distances $(425-850 \mathrm{~m})$ were observed in a study of the behavioural responses of harbour seals to human disturbances at their haul-out locations in relation to the breeding cycle (Andersen et al. 2012). Therefore, based on our results and earlier findings (Niemi et al. 2012), we recommend that $800 \mathrm{~m}$ should be taken as the minimum size for a

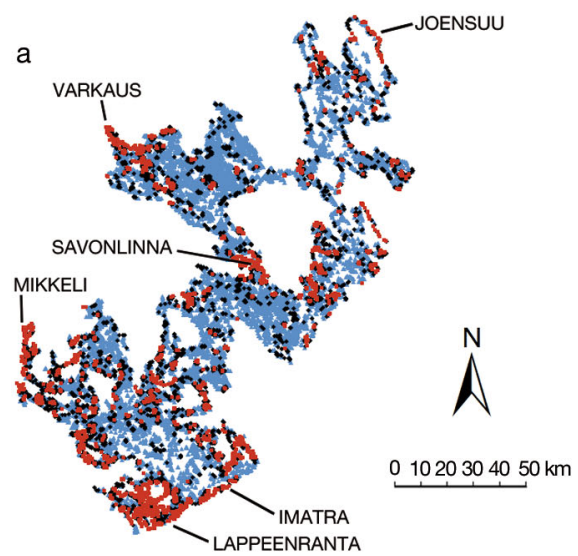

$P($ Perinatal death $)=0-0.1$

$P($ Perinatal death $)=0.1-0.35$

$P($ Perinatal death $)=0.35-0.72$

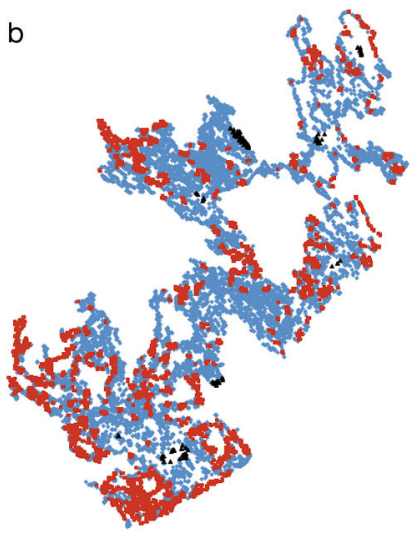

Regular breeding

Edge breeding

Weakened breeding
Fig. 6. (a) Random forest model probabilities of perinatal death of Saimaa ringed seals Pusa hispida saimensis, based on distances from the 100 nearest buildings at $1 \mathrm{~km}$ shoreline intervals and (b) a oneclass support vector machine modelbased classification of the shores of Lake Saimaa in terms of suitability for seal breeding at $1 \mathrm{~km}$ shoreline intervals. Towns (>20 000 inhabitants) are labelled in (a) 
buffer zone between birth lairs and potential sources of human disturbance. Our results with regard to the density of buildings and their closeness to a lair site support previous suggestions of a heightened sensitivity of Saimaa ringed seals to human disturbance during the breeding season (e.g. Sipilä 2003, Ministry of the Environment 2011). Further studies are needed to find out the underlying mechanisms of increased mortality. It has been suggested that humancaused disturbance is analogous to predation risk and that it generates physiological and/or behavioural responses (Frid \& Dill 2002). We argue that seals perceive, e.g. humans, pets and motor vehicles moving on ice mainly by hearing, and this triggers anti-predator behaviour resulting in a trade-off between parental investment and survival in Saimaa ringed seals that ultimately affects breeding success. Similar findings of indirect effects of human disturbance have been noted for nesting birds (Beale \& Monaghan 2004).

The quality of Lake Saimaa shorelines as a seal breeding habitat varies based on the predicted haulout:birth lair ratio in relation to the 100 nearest buildings. Our OCSVM modelling suggests that an average of 6.6 annual haul-out lairs from earlier years are required for each birth lair in the regular breeding area (blue areas in Fig. 6b), and that the number of haul-out lairs required will be larger in densely builtup areas (10.4 haul-out lairs, red areas in Fig. 6b), and also in sparsely populated areas (8.4 haul-out lairs, black areas in Fig. 6b). The result for densely built-up areas may be explained by the fact that there is more disturbance, and hence those areas are not optimal for seal breeding. In areas with low building density, but few Saimaa ringed seals, coincidence is probably one of the most significant factors affecting breeding success. Despite the low number of buildings and thus the low incidence of disturbance, breeding success may remain poor for some unknown reason(s). One such area is the Kolovesi basin (see Fig. 1), which has also been mentioned in a genetic study of seals (Valtonen et al. 2014) as having an extremely limited gene flow to and from other lake basins.

Most of the shoreline of Lake Saimaa still provides potential sites for birth lairs of the ringed seal, but land use for building purposes is so intensive on $29 \%$ of the shoreline that regular breeding is no longer possible. This is alarming, as according to legally approved master plans (as of 2013), around 8000 new summer cottages will be built on the shores of the distribution area of the ringed seal in Lake Saimaa during the next 20 to $25 \mathrm{yr}$, which means that a large part of the subspecies' breeding habitat will decline in quality or vanish due to human land use. The areas where regular breeding is no longer likely are typically located around towns and other human population centres, and these are the areas where building activities should be focussed in the future, leaving the areas of regular or edge breeding undeveloped or only sparsely developed.

Determining and evaluating the impacts of anthropogenic disturbances forms a central part of the strategy for protecting the Saimaa ringed seal, and in the light of our results, we must inevitably conclude that human disturbance via the direct and indirect effects of intensive land use may have a substantial effect on this endangered population. Thus, it can be expected that increasing human activity together with climate change will exacerbate effects such as elevated perinatal pup mortality. To safeguard the remaining breeding habitats, we recommend the establishment of adequate buffer zones between the lair locations and potential sources of disturbance and suggest that these should be taken into account in land use planning as soon as possible.

Acknowledgements. We thank an anonymous statistician for invaluable statistical advice. We are grateful to Arto Ustinov for his insightful comments and suggestions on earlier versions of this manuscript, and to the Ministry of the Environment, the Raija and Ossi Tuuliainen Foundation, the Maj and Tor Nessling Foundation and Saimaa seal LIFE+ (LIFE12NAT/FI/000367) for funding this study. We also thank 2 anonymous reviewers for valuable comments that benefitted the manuscript. This paper is part of a series of contributions to the national action plan and conservation strategy for the Saimaa ringed seal.

\section{LITERATURE CITED}

Andersen SM, Teilmann J, Dietz R, Schmidt NM, Miller LA (2012) Behavioural responses of harbour seals to humaninduced disturbances. Aquat Conserv 22:113-121

Atkinson S (1997) Reproductive biology of seals. Rev Reprod 2:175-194

Auttila M (2015) The endangered Saimaa ringed seal in a changing climate-challenges for conservation and monitoring. PhD dissertation, University of Eastern Finland, Joensuu

Auttila M, Niemi M, Skrzypczak T, Viljanen M, Kunnasranta M (2014) Estimating and mitigating perinatal mortality in the endangered Saimaa ringed seal (Phoca hispida saimensis) in a changing climate. Ann Zool Fenn 51: 526-534

Beale MC, Monaghan P (2004) Human disturbance: people as predation-free predators? J Appl Ecol 41:335-343

Blundell GM, Pendleton GW (2015) Factors affecting haulout behavior of harbor seals (Phoca vitulina) in tidewater glacier inlets in Alaska: Can tourism vessels and seals coexist? PLOS ONE 10:e125486 
Breiman L (1996) Bagging predictors. Mach Learn 24: 123-140

Breiman L (2001) Random forests. Mach Learn 45:5-32

Chang CC, Lin CJ (2011) LIBSVM: a library for support vector machines. ACM Trans Intell Syst Technol 2:27: $1-27: 27$

Cortes C, Vapnik V (1995) Support vector networks. Mach Learn 20:273-297

* Díaz-Ruiz F, Caro J, Delibes-Mateos M, Arroyo B, Ferreras P (2016) Drivers of red fox (Vulpes vulpes) daily activity: prey availability, human disturbance or habitat structure? J Zool (Lond) 298:128-138

Drake JM, Randin C, Guisan A (2006) Modelling ecological niches with support vector machines. J Appl Ecol 43: 424-432

Ellenberg U, Mattern T, Seddon PJ, Jorquera GL (2006) Physiological and reproductive consequences of human disturbance in Humboldt penguins: the need for speciesspecific visitor management. Biol Conserv 133:95-106

Ellenberg U, Setiawan AN, Cree A, Houston DM, Seddon PJ (2007) Elevated hormonal stress response and reduced reproductive output in yellow-eyed penguins exposed to unregulated tourism. Gen Comp Endocrinol 152:54-63

Foody GM, Mathur A, Sanchez-Hernandez C, Boyd DS (2006) Training set size requirements for the classification of a specific class. Remote Sens Environ 104:1-14

*Fowler GS (1999) Behavioral and hormonal responses of Magellanic penguins (Spheniscus magellanicus) to tourism and nest site visitation. Biol Conserv 90:143-149

Frid A, Dill LM (2002) Human-caused disturbance stimuli as a form of predation risk. Conserv Ecol 6:11

* Guo Q, Li W, Liu Y, Tong D (2011) Predicting potential distributions of geographic events using one-class data: concepts and methods. Int J Geogr Inf Sci 25:1697-1715

Helle E, Hyvärinen H, Sipilä T (1984) Breeding habitat and lair structure of the Saimaa ringed seal Phoca hispida saimensis Nordq. in Finland. Acta Zool Fenn 172: 125-127

Henry E, Hammill MO (2001) Impact of small boats on the haul out activity of harbour seals (Phoca vitulina) in Métis Bay, Saint Lawrence Estuary, Québec, Canada. Aquat Mamm 27:140-148

Kenyon KW (1972) Man versus the monk seal. J Mammal 53: 687-696

Kohavi R (1995) A study of cross-validation and bootstrap for accuracy estimation and model selection. In: Mellish CS (ed) IJCAI'95 Proceedings of the 14th international joint conference on artificial intelligence. Morgan Kaufmann Publishers, San Francisco, CA, p 1137-1143

Kokko H, Helle E, Lindström J, Ranta E, Sipilä T, Courchamp F (1999) Backcasting population sizes of ringed and grey seals in the Baltic and Lake Saimaa during the 20th century. Ann Zool Fenn 36:65-73

Koskela JT, Kunnasranta M, Hämäläinen E, Hyvärinen H (2002) Movements and use of haul-out sites of radiotagged Saimaa ringed seal (Phoca hispida saimensis Nordq.) during the open-water season. Ann Zool Fenn 39:59-67

Kovacs KM, Innes S (1990) The impact of tourism on harp seals (Phoca groenlandica) in the Gulf of St. Lawrence, Canada. Appl Anim Behav Sci 26:15-26

Kovacs KM, Aguilar A, Aurioles D, Burkanov V and others (2012) Global threats to pinnipeds. Mar Mamm Sci 28: 414-436
Kunnasranta M (2001) Behavioural biology of two ringed seal (Phoca hispida) subspecies in the large European lakes Saimaa and Ladoga. PhD dissertation, University of Joensuu

Kunnasranta M, Niemi M, Auttila M (2016) Conservation biology of the Saimaa ringed seal: from research to actions. Suom Riista 62:71-82 (in Finnish with English summary)

Kuusisto E (1999) Basin and balances. In: Kuusisto E (ed) Saimaa, a living lake. Tammi, Helsinki, p 21-39

Keblond M, Dussault C, Ouellet JP (2013) Avoidance of roads by large herbivores and its relation to disturbance intensity. J Zool (Lond) 289:32-40

Liukko UM, Henttonen H, Hanski IK, Kauhala K, Kojola I, Kyheröinen EM, Pitkänen J (2016) Suomen nisäkkäiden uhanalaisuus 2015 - The 2015 red list of Finnish mammal species. Ympäristöministeriö \& Suomen ympäristökeskus,

London JM, Ver Hoef JM, Jeffries SJ, Lance MM, Boveng PL (2012) Haul-out behavior of harbor seals (Phoca vitulina) in Hood Canal, Washington. PLOS ONE 7:e38180

Mattlin R (1978) Pup mortality of the New Zealand fur seal (Arctocephalus fosteri, Lesson). NZ J Ecol 1:138-144

*Metsähallitus Parks \& Wildlife Finland (2016) Hyljekanta 2016 (Saimaa ringed seal population, in Finnish). www. metsa.fi/saimaannorppa/hyljekanta2016 (accessed 18 January 2017)

Mierswa I, Wurst M, Klinkenberg R, Scholz M, Euler T (2006) Yale: rapid prototyping for complex data mining tasks. In: Ungar L, Craven M, Gunopulos D, Eliassi-Rad $\mathrm{T}$ (eds) Proceedings of the 12th ACM SIGKDD international conference on knowledge discovery and data mining (KDD '06). ACM, New York, NY, p 935-940

Ministry of the Environment (2011) Conservation strategy and action plan for the Saimaa ringed seal. Ministry of the Environment, Helsinki (in Finnish)

*Morán-López R, Sánchez Guzmán JM, Borrego EC, Sánchez AV (2006) Nest-site selection of endangered cinereous vulture (Aegypius monachus) populations affected by anthropogenic disturbance: present and future conservation implications. Anim Conserv 9: 29-37

Müllner A, Linsenmair KE, Wikelski M (2004) Exposure to ecotourism reduces survival and affects stress response in hoatzin chicks (Opisthocomus hoazin). Biol Conserv 118:549-558

Muñoz-Marí J, Bruzzone L, Camps-Vails G (2007) A support vector domain description approach to supervised classification of remote sensing images. IEEE Trans Geosci Remote Sens 45:2683-2692

Niemi M, Auttila M, Viljanen M, Kunnasranta M (2012) Movement data and their application for assessing the current distribution and conservation needs of the endangered Saimaa ringed seal. Endang Species Res 19: 99-108

Niemi M, Auttila M, Viljanen M, Kunnasranta M (2013a) Home range, survival and dispersal of endangered Saimaa ringed seal pups: implications for conservation. Mar Mamm Sci 29:1-13

Niemi M, Auttila M, Valtonen A, Viljanen M, Kunnasranta M (2013b) Haulout patterns of Saimaa ringed seals and their response to boat traffic during the moulting season. Endang Species Res 22:115-124

Nyman T, Valtonen M, Aspi J, Ruokonen M, Kunnasranta M, Palo JU (2014) Demographic histories and genetic 
diversities of Fennoscandian marine and landlocked ringed seal subspecies. Ecol Evol 4:3420-3434

Official Statistics of Finland (OSF) (2015) Buildings and freetime residences (e-publication). ISSN=1798-6796. Freetime Residences 2015. Statistics Finland, Helsinki

Oiva (2015) Ympäristö- ja paikkatietopalvelu (Environment and geographic information database). Ice cover and water level data. http://wwwp2.ymparisto.fi/scripts/oiva.asp (accessed July 2015) (in Finnish)

Population Register Centre, Population Information System, Building and Dwelling Register (2013) Building information. http://vrk.fi/en/building-information (accessed November 2014)

Rautio A, Niemi M, Kunnasranta M, Holopainen I, Hyvärinen H (2009) Vocal repertoire of the Saimaa ringed seal (Phoca hispida saimensis) during the breeding season. Mar Mamm Sci 25:920-930

Regel J, Pütz K (1997) Effect of human disturbance on body temperature and energy expenditure in penguins. Polar Biol 18:246-253

Schölkopf B, Platt JC, Shawe-Taylor J, Smola AJ, Williamson RC (2001) Estimating the support of a high-dimensional distribution. Neural Comput 13:1443-1471

Selman W, Qualls C, Owen JC (2013) Effects of human disturbance on the behavior and physiology of an imperiled freshwater turtle. J Wildl Manag 77:877-885

Sipilä T (1990) Lair structure and breeding habitat of the Saimaa ringed seal (Phoca hispida saimensis Nordq.) in Finland. Finn Game Res 47:11-22

Sipilä T (2003) Conservation biology of Saimaa ringed seal (Phoca hispida saimensis) with reference to other Euro-

Editorial responsibility: Clive McMahon,

Hobart, Tasmania, Australia pean seal populations. PhD dissertation, University of Helsinki

Sipilä T, Hyvärinen H (1998) Status and biology of Saimaa (Phoca hispida saimensis) and Ladoga (Phoca hispida ladogensis) ringed seals. In: Heide-Jørgensen MP, Lydersen $C$ (eds) Ringed seals in the North Atlantic. NAM MCO Sci Publ 1:83-99

Stevens MA, Boness DJ (2003) Influences of habitat features and human disturbance on use of breeding sites by a declining population of southern fur seals (Arctocephalus australis). J Zool (Lond) 260:145-152

* Valtonen M, Palo J, Ruokonen M, Kunnasranta M, Nyman T (2012) Spatial and temporal variation in genetic diversity of an endangered freshwater seal. Conserv Genet 13: 1231-1245

*Valtonen M, Palo JU, Aspi J, Ruokonen M, Kunnasranta M, Nyman T (2014) Causes and consequences of fine-scale population structure in a critically endangered freshwater seal. BMC Ecol 14:22

* Valtonen M, Heino M, Aspi J, Buuri H and others (2015) Genetic monitoring of a critically-endangered seal population based on field-collected placentas. Ann Zool Fenn 52:51-65

Weimerskirch H, Shaffer SA, Mabille G, Martin J, Boutard O, Rouanet JL (2002) Heart rate and energy expenditure of incubating wandering albatrosses: basal levels, natural variation, and the effects of human disturbance. J Exp Biol 205:475-483

Wheat RE, Wilmers CC (2016) Habituation reverses fearbased ecological effects in brown bears (Ursus arctos). Ecosphere 7:e01408

Submitted: March 14, 2017; Accepted: August 22, 2017 Proofs received from author(s): October 2, 2017 